\title{
MANAJEMEN LAYANAN KHUSUS UNIT KOPERASI BERBASIS E-MONEY PADA PONDOK PESANTREN MODERN DI JAWA TIMUR
}

\author{
Linatul Fatimah \\ UIN Kiai Haji Achmad Siddiq Jember \\ lina61360@gmail.com \\ Siti Aminah \\ UIN Kiai Haji Achmad Siddiq Jember \\ siti.aminaprayoga@gmail.com
}

DOI: 10.35719/jieman.v3i2.72

\begin{abstract}
Abstrak
Manajemen layanan khusus unit koperasi berbasis e-money dibentuk untuk mempermudah dan memperlancar pembelajaran, serta dapat memenuhi kebutuhan peserta didik pada unit koperasi berbasis e-money. E-money sendiri bertujuan untuk memberikan manfaat dan kemudahan dalam pengelolaan keuangan dan pencatatan transaksi. Tujuan penulisan ini adalah untuk mendeskripsikan perencanaan, pengorganisasian, pelaksanaan, serta pengawasan dan evaluasi layanan khusus unit koperasi pada pondok pesantren modern di Jawa Timur. Penelitian ini menggunakan jenis penelitian kualitatif dengan pendekatan studi kasus. Teknik pengumpulan data menggunakan observasi partisipasi yang pasif, wawancara semistruktur, dan dokumentasi. Hasil penelitian ini yaitu 1) Perencanaan unit koperasi berbasis e-money terdiri atas perencanaan jangka panjang seperti penerapan e-money dan menyempurnakan pembukuan keuangan dan perencanaan jangka pendek seperti penyelenggaraan rapat, meningkatkan usaha toko; 2) Pengorganisasian
\end{abstract}


unit koperasi berbasis e-money terdiri dari rapat anggota tahunan, pengurus, pengawas, dan anggota; 3 ) Pelaksanaan unit koperasi berbasis emoney berwujud beberapa usaha yaitu usaha toko makanan dan seragam, laundry, dan wartel; 4) Pengawasan unit koperasi berbasis e-money dilakukan setiap hari dengan terjun langsung dan evaluasi yaitu laporan keuangan koperasi dalam bentuk print out.

Kata Kunci: manajemen layanan khusus, koperasi, e-money

\begin{abstract}
Management of special service cooperative unit based e-money is to make it easy and to expedite learning, and can meet the needs of student's on the cooperative unit based e-money. The purpose of e-money is to provide benefits and to ease of managing and recording transactions. The purpose of this study was to describe about planning, organizing, actuating, controlling and evaluation of the special service by cooperative unit based e-money at a boarding school in East Java. This study uses a qualitative descriptive with case study approach. Data collection technique using a passive observation, a semistructured interview, and a documentation. The research findings are 1) There are two of plan: long term planning as application of e-money and to perfecting financial bookkeeping. Short term planning as holding meetings, increase shop business; 2) Organizing consists of the annual member meeting, administrator, supervisor, and members; 3) Actuating there are some effort's namely food store, uniform store, laundry, and wartel (phone place); 4) Controlling is carried out each every day by jump right in cooperative and evaluation is financial statement by print out.
\end{abstract}

Keywords: management of special service, cooperative, e-money

\title{
Pendahuluan
}

Manajemen layanan khusus merupakan suatu proses kegiatan memberikan pelayanan kebutuhan kepada peserta didik untuk menunjang kegiatan pembelajaran agar tujuan pendidikan dapat tercapai secara efektif dan efisien. Manajemen layanan khusus diterapkan dan diorganisasikan untuk mempermudah atau memperlancar pembelajaran, serta dapat memenuhi kebutuhan 
khusus siswa di sekolah. ${ }^{1}$ Unit koperasi berbasis e-money pada pondok pesantren modern di Jawa Timur ini dikelola oleh pengasuh dan para ustadzah. Sementara itu santri berperan sebagai konsumen atau pembeli. Pada hakikatnya koperasi sekolah harusnya beranggotakan pengurus berupa santri yang terpilih agar mereka belajar terkait entrepreneur sejak dini. ${ }^{2}$

Koperasi Pondok Pesantren atau dikenal dengan Kopontren merupakan koperasi yang didirikan di lingkungan pondok pesantren guna menunjang kebutuhan warga yang berada di dalamnya. Kopontren juga dapat diartikan sebagai pondok pesantren yang memiliki badan usaha yang berbentuk koperasi dan anggotaanggotanya adalah masyarakat pesantren baik yang berada di dalam maupun di luar pondok pesantren. ${ }^{3}$

Electronic money atau yang lebih dikenal dengan e-money merupakan salah satu kemajuan teknologi informasi akuntansi yang diciptakan agar bisa mengetahui dan mengidentifikasi suatu pembayaran secara otomatis dengan menggunakan virtual number yang bertujuan untuk memberikan manfaat dan kemudahan dalam pengelolaan keuangan dan pencatatan transaksi. E-Money pada hakikatnya sama saja dengan uang kertas yang selama ini kita pakai. Bedanya hanya wujudnya saja, kalau dulu kita pakai kertas sebagai wujudnya, maka di masa sekarang ini, yang digunakan adalah data dalam bentuk digital atau elektronik. ${ }^{4}$

Pelaksanaan koperasi pesantren bukan hanya satu orang saja yang mengelola, melainkan dua bahkan lebih. Dalam hal ini perlu adanya kerjasama antara satu dengan lainnya untuk mencapai tujuan

${ }^{1}$ Kompri, Standardisasi Kompetensi Kepala Sekolah: Pendekatan Teori Untuk Praktik Profesional, (Jakarta: Kencana, 2017), 168.

${ }^{2}$ A. A. Ketut Jelantik, Menjadi Kepala Sekolah yang Profesional: Panduan Menuju PKKS, (Yogyakarta: Deepublish, 2015), 3-4.

${ }^{3}$ Ade Tryanda, "Peran Koperasi Pondok Pesantren dalam Meningkatkan Ekonomi Pondok Pesantren Hidayatul Mubtadi'ien Asrama Putra Sunan Gunung Jati Ngunut Tulungangung", (Skripsi: UIN Maulana Malik Ibrahim Malang, 2018), 19.

${ }^{4}$ Ahmad Sarwat, Halal Haram E-Money dalam Timbangan Hukum Syariah Kontemporer, (Jakarta: Lentera Islam, t.th), 5-8. 
yang maksimal. Suatu pekerjaan yang dikerjakan dengan gotong royong akan berdampak lebih besar pula. Sebab, pekerjaan yang dikerjakan dengan gotong royong mempunyai spirit kebersamaan yang kuat, hingga dampaknya tersebut semakin cepat menyebar dan luas, serta pekerjaan akan terasa lebih ringan bila dikerjakan secara bersama-sama sesuai dengan job description. Sama halnya dengan koperasi pesantren akan berjalan lebih baik dengan adanya kerjasama yang baik pula.

Manfaat koperasi bagi lembaga pendidikan yaitu diantaranya: 1) Mendidik, menanamkan, dan memelihara suatu kesadaran hidup bergotong royong dan setia kawan, 2) Memupuk rasa cinta kepada sekolah, 3) Memelihara dan mengembangkan usaha, mempertinggi mutu pengetahuan dan keterampilan, 4) Menanamkan dan memupuk rasa tanggung jawab dalam hidup bergotong royong dalam masyarakat, 5) Memelihara hubungan baik dan saling pengertian yang mendalam diantara warga lembaga pendidikan. ${ }^{5}$

Ada beberapa kajian terdahulu yang relevan dengan penelitian ini. Pertama, Jaleha dalam skripsinya yang berjudul Implementasi Manajemen Layanan Khusus di MAN 2 Model Banjarmasin. ${ }^{6}$ Kedua, Rosana Hayati dalam skripsinya yang berjudul Implementasi Layanan Khusus Unit Koperasi di TA/TK Al-Azhar Syifa Budi Solo Tahun 2018/2019. ${ }^{7}$ Ketiga, Hasan Baharun dan Rizaqil Ardillah dalam jurnalnya yang berjudul Virtual Account Santri Ikhtiyar Pesantren dalam Memberikan Layanan Prima Berorientasi Customer Satisfaction. ${ }^{8}$ Keempat, I Nyoman Suraja Antarajaya dalam

${ }^{5}$ Ade Tryanda, "Peran Koperasi Pondok Pesantren dalam Meningkatkan Ekonomi Pondok Pesantren Hidayatul Mubtadi'ien Asrama Putra Sunan Gunung Jati Ngunut Tulungangung," 24-25.

${ }^{6}$ Jaleha, "Implementasi Manajemen Layanan Khusus di MAN 2 Model Banjarmasin',” (Skripsi: UIN Antasari Banjarmasin, 2017), 56-72.

${ }^{7}$ Rosana Hayati, "Implementasi Layanan Khusus Unit Koperasi di TA/TK Al-Azhar Syifa Budi Solo Tahun 2018/2019'," (Skripsi: Surakarta, Institut Agama Islam Negeri Surakarta, 2018), 65-67.

${ }^{8}$ Hasan Baharin dan Ardillah Rizaqil, "Virtual Account Santri: Ikhtiyar Pesantren dalam Memberikan Layanan Prima Berorientasi Customer Satisfaction'," Jurnal Ekonomi Islam, Vol.1o, No. 1 (2019): 15-16. 
jurnal ilmiahnya yang berjudul Sistem Informasi Penjualan Pada Koperasi Sekolah Menengah Atas Berbasis WEB. ${ }^{9}$ Eni Hidayati dalam skripsinya yang berjudul Dampak Penerapan E-Money Bagi Proses Administrasi Keuangan di Sekolah Dasar Muhammadiyah 1 Ketelan Surakarta. ${ }^{1}$ Nurkholish Majid dan Susilo Surahman dalam artikel berjudul Pelatihan Sistem Administrasi Keuangan Sekolah dengan Software SAK di Jaringan Sekolah Muhammadiyah Se-Kabupaten Boyolali. ${ }^{1}$

Jadi, perbedaan penelitian terdahulu yang telah diuraikan di atas dengan penelitian ini terletak pada lokasi penelitian dan konteks yang diteliti. Dalam penelitian ini, lebih fokus kepada manajemen layanan khusus unit koperasi berbasis e-money. Kegiatan ini dimulai dari langkah perencanaan, pengorganisasian, pelaksanaan, serta pengawasan dan evaluasi. Pondok pesantren meningkatkan mutu pelayanan koperasi pesantren dengan menerapkan e-money guna untuk memudahkan transaksi santri serta meminimalisir angka kehilangan uang. Koperasi pesantren ini dikelola oleh pengasuh dan para ustadzah. Sedangkan santri berperan sebagai konsumen atau pembeli.

Secara teoritis penelitian ini memberikan sumbangan pemikiran serta dapat memberikan khazanah keilmuan baru dalam bidang penerapan layanan khusus bidang koperasi di lembaga pesantren. Secara praktis, penetian ini dapat menjadi bahan acuan dan pertimbangan bagi pengelolaan layanan khusus, khususnya dalam bidang koperasi; sebagai bahan informasi bagi Kepala satuan pendidikan dalam melaksanakan layanna khusus, khususnya dalam

${ }^{9}$ I Nyoman Suraja Antarajaya, “'Sistem Informasi Penjualan Pada Koperasi Sekolah Menengah Atas Berbasis WEB'," Jurnal Ilmiah Pendidikan Citra Bakti, Vol. 6, no. No. 1 (2019): 87-99.

${ }^{1}$ Eni Hidayati, "Dampak Penerapan E-Money ${ }^{0}$ Bagi Proses Administrasi Keuangan di Sekolah Dasar Muhammadiyah 1 Ketelan Surakarta"," (Skripsi: Universitas Muhammadiyah Surakarta, 2019).

1 Nurkholish Majid dan Surahman Susilo, “Pelatihan Sistem Administrasi Keuangan Sekolah dengan Software SAK di Jaringan Sekolah Muhammadiyah SeKabupaten Boyolali'," Jurnal Abdidas, Vol. 1, no. No. 5 (2020): 379-84. 
bidang koperasi; menambah literatur bagi peneliti lain yang akan meneliti layanan khusus unit koperasi di lembaga pesantren.

\section{Pembahasan}

\section{Perencanaan Layanan Khusus Unit Koperasi Berbasis E-Money di Pondok Pesantren}

Perencanaan tidak lain merupakan kegiatan untuk menetapkan tujuan yang akan dicapai beserta cara-cara untuk mencapai tujuan tersebut. Menurut T. Handoko yang dikutip dalam buku konsep dasar manajemen pendidikan di sekolah oleh Daryanto dan Mohammad farid mengemukakan bahwa, "Terdapat empat tahap dalam perencanaan, yaitu: 1) Menetapkan tujuan atau serangkaian tujuan. 2) Merumuskan keadaan saat ini. 3) Mengidentifikasikan segala kemudahan dan hambatan. 4) Mengembangkan rencana atau serangkaian kegiatan untuk pencapaian tujuan”. ${ }^{1}$

Menurut Sarinah dan Mardalena yang dikutip dalam bukunya yang berjudul Pengantar Manajemen menyatakan bahwa, perencanaan merupakan suatu proses yang menyangkut upaya yang dilakukan untuk mengantisipasi kecenderungan di masa yang akan datang dan penentuan strategi dan taktik yang tepat untuk mewujudkan target dan tujuan organisasi. ${ }^{1}$

Perencanan layanan khusus unit koperasi berbasis e-money di pondok pesantren diadakan setiap satu tahun sekali diadakan rapat yaitu pada bulan Juli. Hal yang melatarbelakangi adanya layanan khusus unit koperasi berbasis e-money yaitu di dalam pondok pesantren ini terdapat komunitas dan memiliki watak yang berbedabeda antara santri satu dengan yang lain, jadi dalam hal ini untuk mencegah santri kehilangan uang serta agar mempermudah dalam pembukuan agar tidak terjadi kekeliruan karena sudah menggunakan sistem otomatis komputer.

1 Daryanto dan Mohammad Farid, Konsep Dasar Manajemen Pendidikan di Sekolah (Yogyakarta: Gava Media, 2013), 162-63.

Deepublish, 2017), 7 .

Sarinah dan Mardalena, Pengantar Manajemen, (Yogyakarta: 
Hal ini sesuai dengan konsep dari buku Wildan Zulkarnain bahwa pada hakikatnya perencanaan adalah proses pengambilan keputusan atau sejumlah alternatif atau pilihan mengenai sasaran dan berbagai cara yang akan dilaksanakan di masa mendatang guna mencapai tujuan, serta pemantauan dan penilaian atas hasil pelaksanaannya. ${ }^{1}$

Modal koperasi diperoleh dari pesantren. Prosedur top up emoney juga sudah terstruktur dengan baik, hanya satu orang saja yang melayani bagian administrasi e-money yaitu kepada pengasuh saja. Hal ini sesuai dengan konsep dari buku Wildan Zulkarnain, bahwa modal koperasi sekolah terdiri dari modal sendiri dan modal pinjaman. Modal sendiri adalah modal yang menanggung resiko, dapat berasal dari simpanan pokok, simpanan wajib, dana cadangan, dan hibah. Adapun modal pinjaman dapat berasal dari anggota, koperasi lainnya atau anggotanya, bank dan lembaga keuangan lainnya, penerbitan obligasi dan surat hutang lainnya, serta sumber lain yang sah. ${ }^{1}$

Adapun kegiatan dalam perencanaan koperasi pesantren, koperasi menerapkan perencanaan jangka panjang dan perencanaan jangka pendek:

1. Perencanaan jangka panjang, contoh pengadaan kantor sekretaris dan kelengkapannya, pelatihan dan kursus-kursus perkoperasian, mengadakan studi komparatif.

2. Perencanaan jangka pendek, contohnya penerbitan administrasi keanggotaan, penyelenggaraan rapat anggota tahunan, pembinaan karyawan koperasi, menyempurnakan sistem pembukuan keuangan, mengusahakan sistem komputerisasi, meningkatkan usaha toko, serta meningkatkan usaha simpan pinjam. $^{1}$

1 Wildan Zulkarnain, Manajemen Layanan Khtusus di Sekolah, (Jakarta: Bumi Aksara, 2018), 2.

1 Zulkarnain, 100-101. 5

1 Amrullah, "Analisis Manajemen Pengelolaan Koperasi Pesantren dalam Mewujudkan Kemandirian Pesantren Ummul Ayman Samalanga," Tadabbur: 
Hal tersebut sejalan dengan pendapat pengasuh pondok pesantren yang memegang jabatan dalam kopontren sebagai ketua layanan khusus unit koperasi:

"Pada kegiatan perencanaan disini terdapat dua macam perencanaan diantaranya perencanaan jangka panjang dan perencanaan jangka pendek. a) Perencanaan jangka panjang, diantaranya merencanakan sistem komputerisasi agar otomatis yaitu menerapkan koperasi pesantren berbasis $e$ money dan menyempurnakan sistem pembukuan keuangan secara otomatis. b) Perencanaan jangka pendek, diantaranya yaitu penyelenggaraan rapat ketika ada masalah mengenai koperasi pesantren, meningkatkan usaha toko seperti memenuhi keperluan santri, pembinaan perkoperasian."1

Berdasarkan hasil data yang ada, diketahui bahwa dalam perencanaan layanan khusus unit koperasi berbasis e-money untuk keamanan dan kenyamanan santri sudah sesuai dengan prosedur manajemen pelaksanaan koperasi berbasis e-money.

\section{Pengorganisasian Layanan Khusus Unit Koperasi Berbasis E- Money di Pondok Pesantren}

Pengorganisasian layanan khusus unit koperasi berbasis $e$ money di pondok pesantren tidak terstruktur, jadi hanya melibatkan pengasuh yang memegang tugas sebagai ketua koperasi, pengawas koperasi pesantren, sekaligus staf administrasi e-money dan semua ustadzah-ustadzah yang menetap di dalam pesantren dan mengabdi di pesantren, santri hanya berperan sebagai customer saja jadi tidak terlibat dalam kepengurusan pesantren.

Hal ini sesuai dengan pandangan Arini Amalia bahwa pengorganisasian merupakan suatu proses menentukan, mengelompokkan, dan pengaturan secara bersama dalam suatu kegiatan untuk mencapai tujuan, menentukan orang-orang akan

Jurnal Peradaban Islam, Vol. 1, no. 2 (1 Oktober 2019): 268, https://doi.org/10.22373/tadabbur.vii2.36.

1 Hikmatul Fauziah, diwawancarai oleh Penulis, (Banyuwangi, 22 April 2021). 
melakukan aktivitas atau kegiatan, menyediakan alat yang diperlukan, menetapkan wewenang yang dapat didelegasikan kepada setiap individu yang akan melaksanakan kegiatan. ${ }^{1}$ Sementara menurut Fayol yang dikutip oleh Rheza Pratama menyatakan, pengorganisasian mempermudah manajer dalam melakukan pengawasan dan menentukan orang yang dibutuhkan untuk melaksanakan tugas yang telah dibagi-bagi tersebut. Pengorganisasian dapat dilakukan dengan cara menentukan tugas apa yang harus dikerjakan, siapa yang harus mengerjakan, bagaimana tugas-tugas tersebut dikelompokkan, siapa yang bertanggung jawab, dan pada tingkatan mana keputusan harus diambil. ${ }^{1}$

Adapun kegiatan dalam pengorganisasian koperasi pesantren, perangkat organisasi koperasi pesantren serta struktur dan perincian tugas organisasi koperasi meliputi:

1. Rapat anggota tahunan merupakan pemegang kekuasaan tertinggi dalam koperasi pesantren yang diadakan sekurangkurangnya satu kali dalam satu tahun.

2. Pengurus koperasi pesantren dipilih dari dan oleh anggota yang dimana pemilihan pengurus diatur secara demokratis dan tata cara pemilihannya diatur dalam anggaran rumah tangga.

3. Pengawas dipilih dari dan oleh anggota dalam rapat anggota dimana pengawas ini berasal dari pimpinan pondok pesantren. ${ }^{2}$

1 Arini Amalia, “Manajemen Layanan Khusus Pondok Pesantren,” Jurnal Manajemen dan Supervisi Pendidikan, Vol. 2, no. 2 (10 Maret 2018): 86, https://doi.org/10.17977/umo25v2i22018po83.

1 Rheza Pratama, Pengantar Manajemen, (Yogyakarta: Deepublish, 2020), 11.

2 Astri Dewanti, "Studi Komparasi Manajemen ${ }^{0}$ Koperasi Pada Pesantren Al-Munawwir Krapyak dengan Pesantren Muhammadiyah Boarding School di Daerah Istimewa Yogyakarta dalam Perspektif Ekonomi Islam,” Jurnal Manajemen Koperasi, Vol. 1, no. 6 (2017): 23-24. 
4. Anggota koperasi pesantren adalah pemilik dan sekaligus pengguna jasa koperasi pesantren. Anggota koperasi pesantren harus dicatat dalam buku daftar anggota. ${ }^{2}$

Hal tersebut sejalan dengan pendapat pengasuh pondok pesantren yang memegang jabatan dalam kopontren sebagai ketua layanan khusus unit koperasi:

"Pada tahap pengorganisasian terdapat perincian tugas organisasi koperasi pesantren yang meliputi: a) Rapat Anggota Tahunan (RAT) koperasi pesantren diadakan sekurang-kurangnya dua kali dalam satu tahun. b) Pengurus koperasi dilakukan oleh setiap semua ustadzah yang menetap di dalam pondok pesantren sesuai dengan jadwal yang sudah ditentukan. c) Pengawas koperasi pesantren ini adalah pengasuh pondok pesantren yaitu Ibu Nyai Hj. Hikamtul Fauziah. d) Keanggotaan koperasi pesantren yaitu pemilik dan pengguna jasa koperasi pesantren." ${ }^{2}$

Berdasarkan dari hasil data yang ada, dapat diketahui bahwa dalam pengorganisasian layanan khusus unit koperasi berbasis $e$ money terdiri dari pengurus koperasi, pengasuh, dan staf administrasi e-money bagian koperasi.

\section{Pelaksanaan Layanan Khusus Unit Koperasi Berbasis E-Money di Pondok Pesantren}

Pelaksanaan merupakan aspek terpenting dalam fungsi manajemen karena merupakan pengupayaan dari berbagai jenis tindakan agar semua anggota kelompok mulai dari atasan sampai bawahan berusaha mencapai sasaran kegiatan sesuai dengan cara yang baik dan benar. ${ }^{2}$

2 Amrullah, "Analisis Manajemen Pengelolaan Koperasi Pesantren dalam Mewujudkan Kemandirian Pesantren Ummul Ayman Samalanga,” 269.

2 Hikmatul Fauziah, diwawancarai oleh Penulis, (Banyuwangi, 22 April 2021).

2 Fathurrahman dkk., Bunga Rampai: Fungsi Månajemen dalam Perspektif Quran dan Hadits, (Surabaya: Cipta Media Nusantara, 2021), 26. 
Pelaksanaan layanan khusus unit koperasi berbasis e-money di pondok pesantren sudah sangat baik. Adapun jenis-jenis layanan khusus unit koperasi berbasis e-money di PPMP Al-Kautsar Banyuwangi ini meliputi:

1. Toko

Adapun perincian kegiatan koperasi pada bidang usaha toko dibagi menjadi dua bagian:

a. Jasa Toko Makanan. Kegiatan jasa toko makanan disini menjual berbagai macam kue, snack atau makanan ringan, minuman dingin dan tidak dingin, mie instan, peralatan mandi, dan lain sebagainya.

b. Jasa Toko Seragam. Kegiatan jasa toko seragam disini menjual mulai dari seragam dan perlengkapan seragamnya, buku mata pelajaran, buku tulis, dan peralatan tulis lainnya.

2. Laundry

Pondok pesantren menetapkan peraturan diwajibkan melaundry bagi santri. Dalam pelaksanaan laundry ini pesantren memberikan kepercayaan dan tanggungjawab kepada orang luar pondok bagian laundry, biaya laundry Rp5.000,00 per kg, dan pesantren hanya mengambil laba Rp1.0oo,oo dan yang Rp4.0oo,oo jasa untuk bagian laundry. Setelah diadakannya peraturan diwajibkan melaundry ini sangat berpengaruh besar terhadap kebersihan pondok seperti jumlah bazar baju sudah turun drastis meskipun kadangkala masih ada karena terkadang santri meletakkan handuk dan baju tidak pada tempatnya. Lalu santri terlihat rapi, bersih, dan harum.

3. Wartel

PPMP Al-Kautsar Banyuwangi juga menyediakan jasa wartel guna untuk santri yang ingin berkomunikasi dengan orang tua dan keluarga lainnya. Dalam hal ini tetap adanya pengawasan oleh ustadzah yang piket menjaga agar santri benar-benar menghubungi orang tuanya. Biaya wartel dihitung setiap menitnya yaitu Rp1.500,oo per menit. 
Penjelasan ini dikuatkan wawancara peneliti kepada ketua koperasi:

"Jasa toko disini ada dua bagian yaitu jasa toko makanan dan jasa toko seragam. Jasa toko makanan menjual berbagai produk mulai dari snack atau makanan ringan, minuman dingin dan tidak dingin, berbagai macam kue, mie instans, peralatan mandi, dan lain-lain. Kemudian, jasa toko seragam meliputi seragam, buku mata pelajaran, buku tulis, dan peralatan tulis lainnya. Terkait jasa laundry, kita memanggil orang luar pondok yang terpercaya untuk menjalankan usaha laundry ini, pesantren hanya mengambil laba Rp. 1.000 per kilonya. Sekarang santri diwajibkan melaundry. Santi sekarang dilarang mencuci baju sendiri. Tempat cuci baju sekarang sudah direnovasi menjadi kamar mandi. Santri juga dilarang mencuci di dalam kamar mandi. Alasan untuk santri diwajibkan melaundry yaitu agar para santri terlihat bersih dan terawat apalagi santri baru biasanya bajunya tidak disetrika. Kadang ada yang seragam putih jadi kuning jadi saya kasian. Akhirnya saya berinisiatif untuk diadakan laundry santri. Hal ini sangat berpengaruh besar terhadap angka bazar baju santri yang berserakan, sudah sangat berkurang dari sebelum-sebelumnya. Tetapi, masih tetap diadakan bazar karena terkadang ada handuk-handuk yang digantung di jendela kamar atau baju digantung di lemarilemari. Selain jasa toko dan jasa laundry ini, koperasi juga menyediakan jasa wartel. Semua pembayarannya melalui kartu e-money yang sudah dimiliki masing-masing siswa. Biaya wartel ini dihitung sesuai menitnya yaitu Rp.1.500,oo per menit."

Hal ini sesuai dengan jurnal yang dikutip oleh Amrullah dan buku yang dikutip oleh Imamul Arifin dan Giana Hadi Wagiana,

2 Hikmatul Fauziah, diwawancarai oleh Penults, (Banyuwangi, 22 April 2021). 
adapun dalam kegiatan pelaksanaan koperasi pesantren, koperasi mengadakan berbagai usaha, diantaranya:

1. Pertokoan

Perkembangan koperasi pesantren banyak dipengaruhi oleh perkembangan pondok yang cukup pesat, baik dari segi jumlah masyarakat pondok yang setiap tahunnya mengalami peningkatan, serta sarana dan prasarana. Seiring dengan perkembangan ini, maka kebutuhan yang diperlukan oleh masyarakat pondok pun menjadi meningkat.

2. Perlengkapan santri

Unit usaha ini menjual berbagai macam perlengkapanperlengkapan yang wajib dimiliki bagi santri, seperti kebutuhan sehari-hari, dan lain-lain. ${ }^{2}$

3. Pelayanan jasa

Selain memberikan dan menyediakan kebutuhan berupa barang. Unit koperasi juga menyediakan pelayanan atau jasajasa. Pelayanan tersebut antara lain dalam bentuk jasa fotocopy, wartel, dan kursus-kursus. ${ }^{2}$

Dampak adanya pelaksanaan layanan khusus unit koperasi berbasis e-money sangat berpengaruh terhadap pesantren dan santri. Karena sejak diterapkannya e-money jumlah santri kehilangan uang sangat berkurang, santri dengan mudah melakukan pembayaran, dan pesantren juga mudah dalam hal pembukuan.

Hal ini sejalan dengan pendapat salah satu santri kelas XI IPA berinisial SAAM pada 15 Maret 2021, mengatakan bahwa:

"Menurut saya dengan adanya sistem e-money ini sangat berpengaruh kepada saya dan santri yang lainnya, karena uang tersimpan dengan aman tidak ada lagi kasus santri kehilangan uang. Pengisian saldo e-money juga sangat

2 Amrullah, "Analisis Manajemen Pengelolaan Koperasi Pesantren dalam Mewujudkan Kemandirian Pesantren Ummul Ayman Samalanga,” 270.

2 Imamul Arifin dan Giana Hadi Wagiana, Menłbuka Cakrawala Ekonomi untuk Kelas XII Sekolah Menengah Atas/ Madrasah Aliyah Program Ilmu Pengetahuan Sosial, (Bandung: PT Setia Purna Inves, 2007), 90-91. 
mudah, seperti setor tunai uang di ATM hanya saja kita setor kepada ibu nyai untuk dimasukan ke e-money kita." ${ }^{2}$

\section{Pengawasan dan Evaluasi Layanan Khusus Unit Koperasi Berbasis E-Money di Pondok Pesantren}

Dalam konteks ini, pengawasan adalah suatu kegiatan dalam organisasi agar pelaksanaan yang dilakukan sesuai dengan yang direncanakan. Pengawasan juga dapat diartikan sebuah proses berkelanjutan untuk menilai kemajuan yang sedang terjadi yang dilakukan oleh pekerja dan seluruh anggota organisasi. ${ }^{2}$

Pengawasan layanan khusus unit koperasi berbasis e-money sudah berjalan sangat baik, efektif, dan efisien. Pengasuh sebagai ketua koperasi melakukan pengawasan untuk mengontrol kinerja ustadzah dengan terjun langsung ke koperasi setiap harinya. Laporan pembukuan berupa hard file dalam bentuk print out. Selama diterapkannya pelaksanaan layanan khusus unit koperasi berbasis $e$ money barang terdata secara terstruktur, tidak ada kekeliruan dalam pembukuan, setiap bulannya selalu ada laba dan tidak terjadi kerugian. Dalam pembukuan sudah tertera pengeluaran, pendapatan, laba, atau rugi sehingga tidak perlu repot-repot untuk menghitung karena hitungan sudah otomatis tidak akan ada kekeliruan.

Kemudian bahasan temuan mengenai evaluasi koperasi ini berupa laporan pembukuan pada akhir bulan. Pada laporan pembukuan ini mengalami peningkatan yang sangat pesat dari sistem sebelumnya yang menggunakan sistem manual. Pada saat ini pembukuan sudah menggunakan sistem otomatis sehingga meminimalisir angka kekeliruan dalam pembukuan. Hal ini menyebabkan evaluasi koperasi pesantren dan pembukuan berjalan secara efektif dan efisien. Adapun evaluasi juga diadakan rapat setiap

2 Sekar Ayu Alya Ma'arif, diwawancarai oleh ${ }^{7}$ Penulis, (Banyuwangi, 15 Maret 2021).

2 Cipta Pramana, dkk., Dasar Ilmu Manajemen̊, (Bandung: Media Sains Indonesia, 2021), 14. 
satu tahun sekali pada akhir tahun setiap bulan Juni dan juga mengadakan perencanaan kembali. Begitupun seterusnya.

Penjelasan mengenai pengawasan dan evaluasi koperasi pondok dikuatkan wawancara peneliti kepada ketua koperasi dan staf administrasi $e$-money. Adapun dalam kegiatan koperasi terkait dengan pengawasan dan evaluasi diantaranya menyatakan bahwa:

"Saya sebagai ketua koperasi pesantren sekaligus pengawas koperasi pesantren melakukan pengawasan terkait kinerja anggota pengurus koperasi dengan terjun langsung ke koperasi setiap waktu buka koperasi, jadi dalam satu hari ada empat kali pengawasan guna untuk tercapainya tujuan koperasi secara efektif dan efisien. Kemudian terkait dengan kegiatan evaluasi koperasi pesantren, evaluasi dilakukan dengan pelaporan pembukuan selama setiap satu bulan sekali setiap tanggal 30 dan dalam pembukuan ini sudah tertera secara otomatis yang berupa print out.Kemudian setiap satu tahun sekali diadakan rapat tentang evaluasi koperasi pesantren yang membahas tentang apa yang sudah dicapai, kendala, dan lain sebagainya. Kemudian adanya perencanaan kembali mengenai koperasi." ${ }^{2}$

Hal ini sesuai dengan konsep dari T. Handoko yang dikutip Daryanto dan Mohammad Farid menjelaskan bahwa, "Pengawasan merupakan suatu usaha yang sistematik untuk menetapkan standar pelaksanaan dengan tujuan-tujuan perencanaan, merancang sistem informasi umpan balik, membandingkan kegiatan nyata dengan standar yang telah ditetapkan sebelumnya, menentukan dan mengukur penyimpangan, serta mengambil tindakan koreksi yang diperlukan untuk menjamin bahwa semua sumber daya perusahaan dipergunakan dengan cara paling efektif dan efisien". ${ }^{3}$

2 Hikmatul Fauziah, diwawancarai oleh Penulis, (Banyuwangi, 22 April 2021).

3 Daryanto dan Mohammad Farid, Konsep Dasar Manajemen Pendidikan di Sekolah, 166-67. 
Jadi, dalam pengawasan dan evaluasi layanan khusus unit koperasi berbasis e-money sudah berjalan dengan sangat baik. Sehingga dengan adanya program ini, menjadikan dampak yang sangat berpengaruh lebih besar terhadap pelaksanaan manajemen layanan khusus unit koperasi berbasis e-money di pondok pesantren ini.

\section{Simpulan}

Manajemen layanan khusus unit koperasi berbasis e-money dilaksanakan sesuai fungsi-fungsi manajemen. Hal itu terdiri atas perencanaan, pengorganisasian, pelaksanaan, serta pengawasan dan evaluasi. Perencanaan mencakup perencanaan jangka panjang dan perencanaan jangka pendek. Pengorganisasian terdiri dari rapat anggota tahunan, pengurus koperasi, pengawas koperasi, serta anggota koperasi pesantren. Pelaksanaan mencakup bidang usaha toko yang terdiri dari toko makanan dan toko seragam, usaha laundry, dan usaha wartel. Pengawasan dilakukan oleh pengasuh dengan terjun langsung ke koperasi agar dapat mengetahui kendalakendala yang dialami selama jam operasional koperasi pesantren. Kemudian evaluasi berupa laporan pembukuan koperasi setiap bulannya dan juga dilakukan rapat setiap satu tahun sekali. Kemudian diadakan perencanaan kembali. Dengan menjalankan keempat fungsi manajemen tersebut maka sampai saat ini terdapat peningkatan dalam pelaksanaan layanan khusus unit koperasi berbasis e-money seperti meminimalisasi angka santri yang kehilangan uang dan pembukuan juga terdata dengan mudah tanpa adanya kekeliruan, bahkan mulai dari diterapkannya layanan khusus unit koperasi berbasis e-money pada tahun 2019 sampai sekarang selalu ada laba setiap tahunnya, jadi tidak pernah mengalami kerugian.

\section{Referensi}

Amalia, Arini. "Manajemen Layanan Khusus Pondok Pesantren." Jurnal Manajemen dan Supervisi Pendidikan, Vol. 2, no. 2 (10 
Maret

2018):

$83-88$.

https://doi.org/10.17977/umo25V2i22018po83.

Amrullah, Amrullah. "Analisis Manajemen Pengelolaan Koperasi

Pesantren dalam Mewujudkan Kemandirian Pesantren Ummul Ayman Samalanga." Tadabbur: Jurnal Peradaban Islam, Vol. 1, no. 2 (1 Oktober 2019): 257-77. https://doi.org/10.22373/tadabbur.vii2.36.

Antarajaya, I Nyoman Suraja. "Sistem Informasi Penjualan Pada Koperasi Sekolah Menengah Atas Berbasis WEB.” Jurnal Ilmiah Pendidikan Citra Bakti, Vol. 6, no. No. 1 (2019): 87-99.

Baharin, Hasan dan Ardillah, Rizaqil. "Virtual Account Santri: Ikhtiyar Pesantren dalam Memberikan Layanan Prima Berorientasi Customer Satisfaction.” Jurnal Ekonomi Islam Vol.10, no. 1 (2019): 15-16.

Daryanto dan Farid, Mohammad. Konsep Dasar Manajemen Pendidikan di Sekolah. Yogyakarta: Gava Media, 2013.

Dewanti, Astri. "Studi Komparasi Manajemen Koperasi Pada Pesantren Al-Munawwir Krapyak dengan Pesantren Muhammadiyah Boarding School di Daerah Istimewa Yogyakarta dalam Perspektif Ekonomi Islam.” Jurnal Manajemen Koperasi, Vol. 1, no. 6 (2017): 23-24.

Fathurrahman, et.al., Bunga Rampai: Fungsi Manajemen dalam Perspektif Quran dan Hadits. Surabaya: Cipta Media Nusantara, 2021.

Hayati, Rosana. "Implementasi Layanan Khusus Unit Koperasi di TA/TK Al-Azhar Syifa Budi Solo Tahun 2018/2019.” Skripsi: Institut Agama Islam Negeri Surakarta, 2018.

Hidayati, Eni. "Dampak Penerapan E-Money Bagi Proses Administrasi Keuangan di Sekolah Dasar Muhammadiyah 1 Ketelan Surakarta." Skripsi: Universitas Muhammadiyah Surakarta, 2019. 
Imamul Arifin dan Giana Hadi Wagiana. Membuka Cakrawala Ekonomi untuk Kelas XII Sekolah Menengah Atas/ Madrasah Aliyah Program Ilmu Pengetahuan Sosial Bandung: PT Setia Purna Inves, 2007.

Jaleha. "Implementasi Manajemen Layanan Khusus di MAN 2 Banjarmasin.” Skripsi: UIN Antasari Banjarmasin, 2017.

Jelantik, A. A. Ketut. Menjadi Kepala Sekolah yang Profesional: Panduan Menuju PKKS, Y Yogyakarta: Deepublish, 2015.

Kompri. Standardisasi Kompetensi Kepala Sekolah: Pendekatan Teori Untuk Praktik Profesional, . Jakarta: Kencana, 2017.

Majid, Surahman, Nurkholish, Susilo. "Pelatihan Sistem Administrasi Keuangan Sekolah dengan Software SAK di Jaringan Sekolah Muhammadiyah Se-Kabupaten Boyolali." Jurnal Abdidas, Vol. 1, no. No. 5 (2020): 379-84.

Pramana, Cipta, dkk. Dasar Ilmu Manajemen. Bandung: Media Sains Indonesia, 2021.

Pratama, Rheza. Pengantar Manajemen. Yogyakarta: Deepublish, 2020.

Sarinah dan Mardalena. Pengantar Manajemen. Yogyakarta: Deepublish, 2017.

Sarwat, Ahmad. Halal Haram E-Money dalam Timbangan Hukum Syariah Kontemporer. Jakarta: Lentera Islam, t.th.

Tryanda, Ade. "Peran Koperasi Pondok Pesantren dalam Meningkatkan Ekonomi Pondok Pesantren Hidayatul Mubtadi'ien Asrama Putra Sunan Gunung Jati Ngunut Tulungangung." Skripsi: UIN Maulana Malik Ibrahim Malang, 2018.

Zulkarnain, Wildan. Manajemen Layanan Khusus di Sekolah. Jakarta: Bumi Aksara, 2018. 